\title{
Fremtidens luftambulansefly i Nord-Norge
}

\author{
Større og raskere er ikke nødvendigvis bedre. Et nytt jetfly i Tromsø er planlagt å erstatte et propellfly i Alta, \\ men kan ikke lande på åtte av Finnmarks 11 flyplasser. Vi frykter at den lokale akuttmedisinske beredskapen \\ forringes og at faren for transportfødsler øker.
}

De regionale helseforetakenes felles foretak, Luftambulansetjenesten, kjøper flytjenester på vegne av foretakene, og en ny anbudsperiode er i anmarsj med kontraktstart 1. juli 2019. Etter en høringsrunde er Luftambulansetjenestens strategidokument nå vedtatt av direktørene i de regionale helseforetakene. Man vil i den nye kontrakten bestille et jetfly som skal plasseres i Tromsø, men fjerner samtidig det ene luftambulanseflyet fra basen i Alta. Tidsskriftet hadde nylig en artikkel om innkjøpsprosessen for nye flytjenester i Luftambulansetjenesten (1). I artikkelen har man ukritisk gjengitt pressemeldingen fra Luftambulansetjenesten.

I høringsnotatet fra Luftambulansetjenesten advarte tjenesten selv mot å fjerne det ene flyet fra Alta, fordi man da mister muligheten for fleksibilitet som flere fly og besetninger på samme base innebærer. Luftambulansebasen i Alta gjennomfører årlig rundt 1800 oppdrag. I 2014 hadde $22 \%$ av oppdragene høyeste hastegrad, og $48 \%$ av oppdragene var primæroppdrag der pasienten hentes direkte fra skadested/legekontor på nærmeste flyplass og fraktes til sykehus.

Tilgjengeligheten av ambulansefly i Alta har de siste årene (2012-14) ligget blant de høyeste i landet og er på over $95 \%$ (Trond Antonsen, personlig meddelelse). Jetflyet, som skal erstatte propellflyet, kan ikke lande på åtte av Finnmarks 11 flyplasser. Bestillingen til Luftambulansetjenesten er blitt mottatt med sterke protester fra både Finnmarkssykehuset, Vest-Finnmark regionråd, Finnmark legeforening, Norsk Sykepleierforbund og en rekke ordførere og brukere av tjenesten. Vi frykter at det å fjerne et fly i Alta vil forringe den gode lokale akuttmedisinske beredskapen som Alta er kjent for, der flysykepleiere og lokal beredskap samarbeider $(2,3)$, fordi tilgjengeligheten av ambulansefly reduseres. Legeforeningen tildelte nylig en kvalitetspris til dette miljøet.

\section{Fare for flere transportfødsler}

Gravide kvinner i Finnmark har lang reisevei til fødeavdelingen. Over $40 \%$ har mer enn én times reisevei, og derfor er det også flest transportfødsler per 1000 kvinner i Finnmark (4). Med 50 mil mellom fødeavdelingene i Kirkenes, Hammerfest og Universitetssykehuset i Nord-Norge setter dette krav til den prehospitale transporttjenesten. For en kvinne med rier på Nordkyn-halvøya vil det ta 4,5 timer med bil uansett hvilket sykehus i Finnmark hun skal til, og lufttransport er derfor eneste alternativ. Da må flyet være ledig og faktisk kunne lande på kort- baneflyplassen. Vi frykter at det vil bli flere transportfødsler med den utryggheten det medfører for den kvinnelige befolkningen, særlig langs kysten av Finnmark.

\section{Finnmark trenger opprustning}

Begrunnelsen for bestilling av et jetfly har vært beredskap for befolkningen på Svalbard og å skaffe kapasitet for overføring av de sykeste intensivpasientene. Svalbard har sykehus med delvis kirurgberedskap, to leger tilgjengelig, døgnvakt med anestesisykepleier/operasjonssykepleier og videokonferanse til Universitetssykehuset NordNorge i Tromsø. Svalbard hadde 78 opp-

\section{«Finnmark trenger en betydelig opprustning for å få samme stan- dard som det nå plan- legges for Svalbard»}

drag i 2015, og en gjennomføringsgrad på $95 \%$, der de avbrutte/avlyste oppdragene hovedsakelig var forårsaket av sikt eller vind på Svalbard. Finnmarkskommunene har varierende legedekning og -kompetanse, ulike fasiliteter på helsesentrene og hadde 1157 ambulanseflyoppdrag i 2015. Om pasienten ikke bor i Hammerfest eller Kirkenes, er transporttiden med bil fra to til fem timer. Tallene viser at Finnmark trenger en betydelig opprustning i beredskapen for luftambulanse for å få samme standard som det nå planlegges for Svalbard.

Det er to ambulansefly i Nord-Norge som er bemannet med anestesilege, i tillegg til ambulanse- og redningshelikoptrene. De to flyene står i Tromsø og Bodø. I den nye bestillingen er dette uendret, men basen i Tromsø skal disponere både jet- og propellfly. Dette krever to besetninger, siden samme piloter ikke flyr begge flytyper. Bedre kapasitet for transport av de sykeste pasientene fra lokalsykehus til universitetsklinikk kan være en viktig begrunnelse for et jetfly, men disse oppdragene har ikke samme hastegrad som primærtransportene. Den hyppigste flydde strekning med pasienter som ble overført til høyere behandlingsnivå i 2015, var fra Hammerfest til Tromsø. Et jetfly kan ikke lande på kortbaneflyplassen i Hammerfest og dermed ikke hente intensivpasienter her - men heller ikke levere pasienter til deres lokalsykehus fra Alta og Porsanger, to befolkninger som utgjør om lag halvparten av Finnmarks befolkning. Selv med jetfly vil transporttid fra flyplass til sykehus bli lenger til Universitetssykehuset Nord-Norge i Tromsø enn til Hammerfest. Å bruke jetfly til de legebemannede flytransportene i Nord-Norge er altså en dårlig idé, både for den delen av den nordnorske befolkningen som bor langs kysten i Finnmark, og for de som bor nær stamflyplasser med lang rullebane.

Hva kan gjøres? Det er ikke medisinsk behov for to fly i Tromsø. Hvis jetflyet i Tromsø ivaretar legeberedskapen, kan de to propellflyene i Alta beholdes. Dersom luftambulanseflyet som er stasjonert i Kirkenes, har anestesilege i beredskap, vil befolkningen på Finnmarkskysten nærme seg samme beredskapsnivå som på Svalbard.

\section{Torben Wisborg \\ torben@wisborg.net \\ Ingrid Petrikke Olsen}

Torben Wisborg (f. 1956) er overlege ved Akuttavdelingen, Finnmarkssykehuset, Klinikk Hammerfest, professor ved Universitetet i Troms $\varnothing$ og leder for Nasjonal kompetansetjeneste for traumatologi, Oslo universitetssykehus, Ullevål. Forfatter har fylt ut ICMJE-skjemaet og oppgir følgende interessekonflikter: Han er medisinsk ansvarlig ved Finnmarkssykehuset for luftambulansebasen i Alta.

Ingrid Petrikke Olsen (f. 1969) er overlege ved Gynekologisk/Obstetrisk avdeling, Finnmarkssykehuset, Klinikk Hammerfest og førsteamanuensis ved Universitetet i Troms $\varnothing$. Hun er medisinsk ansvarlig ved Finnmarkssykehuset for Fødestua i Alta.

Forfatter har fylt ut ICMJE-skjemaet og oppgir ingen interessekonflikter.

\section{Litteratur}

1. Fjellhaug MS. Jetfly i luftambulansetjenesten. Tidsskr Nor Legeforen 2016; 136: 1031

2. Wisborg T, Bjerkan B. Air ambulance nurses as expert supplement to local emergency services Air Med J 2014; 33: 40-3.

3. Wisborg T. Flysykepleiere gir bedre akuttmedisin. Tidsskr Nor Legeforen 2014; 134: 609.

4. Engjom HM, Morken NH, Norheim OF et al. Availability and access in modern obstetric care: a retrospective population-based study. BJOG 2014 121: $290-9$.

Mottatt 7.8. 2016 og godkjent 8.8. 2016. Redaktør: Ketil Slagstad.

Publisert først på nett. 